NBER WORKING PAPER SERIES

\title{
PLAYING WITH FIRE: \\ CIGARETTES, TAXES AND COMPETITION FROM THE INTERNET
}

\author{
Austan Goolsbee \\ Michael Lovenheim \\ Joel B. Slemrod \\ Working Paper 15612 \\ http://www.nber.org/papers/w15612
}

\author{
NATIONAL BUREAU OF ECONOMIC RESEARCH \\ 1050 Massachusetts Avenue \\ Cambridge, MA 02138 \\ December 2009
}

We wish to thank Jonathan Gruber, James Poterba, Raj Chetty, Ward Hanson, John Bound, Maria Fitzpatrick, two anonymous referees, and participants at seminars at UC Berkeley, the University of Chicago, and the NBER Summer Institute for helpful comments. We also thank Jane Dokko, Peter Katuscak, Pablo Pena, Svetla Tzenova and Jongsang Park for research assistance, and the American Tax Policy Institute and the Searle Freedom Trust for financial support. The views expressed herein are those of the author(s) and do not necessarily reflect the views of the National Bureau of Economic Research.

NBER working papers are circulated for discussion and comment purposes. They have not been peerreviewed or been subject to the review by the NBER Board of Directors that accompanies official NBER publications.

(C) 2009 by Austan Goolsbee, Michael Lovenheim, and Joel B. Slemrod. All rights reserved. Short sections of text, not to exceed two paragraphs, may be quoted without explicit permission provided that full credit, including $\odot$ notice, is given to the source. 
Playing With Fire: Cigarettes, Taxes and Competition From the Internet Austan Goolsbee, Michael Lovenheim, and Joel B. Slemrod

NBER Working Paper No. 15612

December 2009

JEL No. H2

\section{ABSTRACT}

This paper documents the rise of the Internet as a source of state-tax-free cigarettes and its impact on taxed sales elasticities. Using data on cigarette tax rates, taxable cigarette sales and individual smoking rates by state from 1980 to 2005 merged with data on Internet penetration, the paper documents that there has been a substantial increase in the sensitivity of taxable cigarette sales to state tax rates that is correlated with the rise of Internet usage within states. The estimates imply that the increased sensitivity from cigarette smuggling over the Internet has lessened the revenue generating potential of cigarette tax increases significantly, although states are still far from the revenue-maximizing tax rates.

Austan Goolsbee

University of Chicago

On Leave

goolsbee@gsb.uchicago.edu

Michael Lovenheim

Cornell University

103 MVR Hall

Ithaca, NY 14853

mfl55@cornell.edu
Joel B. Slemrod

University of Michigan Business School

Room R5396

Ann Arbor, MI 48109-1234

and NBER

jslemrod@umich.edu 
Cigarette taxes traditionally have presented policymakers with a benign tradeoff between revenue and public health. On one hand, if demand is inelastic, raising cigarette taxes can generate substantial revenue with low excess burden. On the other hand, if cigarette taxes are ineffective at raising revenue because of behavioral responses, they will reduce consumption, thereby saving lives and preventing disease.

Cigarette smuggling, however, endangers this happy tradeoff. If increasing cigarette taxes only serves to increase smuggling, these taxes may be ineffective at both raising revenue and reducing consumption. In this context, the rise of the Internet and the availability of taxfree, mail-order cigarettes present a potentially serious threat to the efficacy of local cigarette taxes. When people can buy online, raising tax rates may generate little additional revenue while at the same time doing nothing to improve health. Instead, people simply become more sensitive in where they choose to buy their cigarettes.

Cigarette tax evasion over the Internet has become an issue of first-order importance in the last several years as many states have significantly raised their cigarette taxes to help close their budget deficits. Since January, 2002, 36 states and the District of Columbia have increased their cigarette tax rates, expecting to raise revenues due to the relatively inelastic demand of cigarettes. ${ }^{1}$ This paper examines whether the rise of the Internet has made taxable cigarette purchases more responsive to state tax rates, thereby reducing the revenuegenerating potential of these taxes without the associated smoking reductions.

While there is a small literature on the effect of taxes on Internet use, this is the first paper to analyze explicitly the impact on the tax responsiveness of consumers of the expanded tax evasion ability that online shopping provides. In earlier work on e-commerce, Austan

\footnotetext{
${ }^{1}$ There is an extensive literature on the demand for cigarettes including Gary Becker, Michael Grossman, and Kevin Murphy (1994) and Jonathan Gruber and Bötond Koszegi (2001). William Evans et al. (1999) and Frank J. Chaloupka and Kenneth Warner (2000) survey the literature.
} 
Goolsbee (2000) shows consumers living in high-tax locations are more likely to shop online.

This paper poses a different though related question to Goolsbee (2000), namely, are tax elasticities higher in states with higher Internet penetration? While our study focuses on cigarette sales, the results shed light on the more general question of how the growth in ecommerce affects the revenue-generating potential of state-level excise taxes. Due to the difficulties inherent in measuring tax evasion, this question has received little attention in the empirical literature.

Cigarettes are a natural place to look for the impact of the Internet on consumer response to taxation because state excise tax rates on cigarettes are particularly high relative to other consumption taxes and because avoidance and evasion, both informal and organized, is rampant. ${ }^{2}$ For example, the number of Internet cigarette merchants located on Native American reservations (where state excise taxes levied on wholesalers often do not apply) and in states with low cigarette taxes have dramatically increased. Although Internet sales are subject to cigarette excise taxes that should be remitted by the consumers to the states where the cigarettes are consumed, little tax is actually collected from these online sales (General Accounting Office (GAO), 2002; 2003). Indeed, the state of New York has attempted to ban Internet cigarette merchants completely and has argued that it loses $\$ 500$ to $\$ 600$ million per year of revenue from Internet, “800 number,” and Indian reservation sales (Ridgewood Economic Associates, Ltd., 2002).

\footnotetext{
${ }^{2}$ Becker, Grossman, and Murphy (1994), Morris Coats (1995), Jerry Thursby and Marie Thursby (2000), Ayda A. Yurekli and Ping Zhang (2000), Matthew Farrelly, et al. (2001), and Gruber, Anindya Sen and Mark Stabile (2003) all document ways that smuggling and proximity to low-tax neighbors make cigarette sales more sensitive to tax rate changes. Michael F. Lovenheim (2008) shows the sensitivity of consumption to the home state price varies systematically by how close consumers live to lower-price borders and estimates between 13-25 percent of cigarettes are purchased in lower-price localities.
} 
In this paper we make use of survey data on Internet use by state and across time as well as state data on taxable cigarette sales to investigate how the growth of the Internet has affected the tax rate elasticity of taxable cigarette sales. The results suggest the rise of online shopping has dramatically increased the sensitivity of in-state taxed purchases to state tax rates. The price elasticity of taxable cigarette sales has risen most in those places where the Internet has grown the fastest and, in magnitude, increased the sensitivity of taxable cigarette sales to state tax rates by 69 percent. We present evidence that the state-specific growth in Internet usage is unrelated to secular changes in sales elasticities absent the presence of online price savings, which implies the increased tax sensitivity is due to Internet smuggling. Our results also imply that the observed increases in the price elasticity of taxable sales since 2000 (Yurekli and Zhang, 2000; Theodore E. Keeler et al., 2001; Mark Stehr, 2005) can be explained in part by the growth in Internet penetration over this time period.

The overall impact of Internet growth on tax revenue is modest thus far, but the impact on the ability of tax increases to generate revenue has been sizable. We estimate the tax increases of 2001 to 2005 might have caused states to collect about 9 percent less revenue than would have been expected without any tax-free Internet sales.

The paper proceeds as follows. Section I discusses the cigarette retail industry and the role of the new Internet sites. Our data and empirical methodology are described in Section II. Section III shows the basic results on taxable cigarette sales, presents taxable sales elasticities, and discusses the revenue implications of our findings. Section IV presents estimates of the relationship between cigarette taxes, cigarette consumption, and Internet smuggling. Section V shows tests of robustness, and Section VI concludes. 


\section{The Cigarette Industry}

With the growth of the Internet, many websites offering cigarettes for sale online have arisen. A GAO report identifies the names and addresses of some 147 such sites in 2002 and said there might be 400 or more such sites in existence (GAO, 2002). With names like www.taxfreecigarettes.com, www.notaxsmokes.com and www.0taxcigs.com, it is clear that vendors are aware of the opportunities the Internet provides for tax evasion. Virtually all of the online merchants are physically located either on American Indian Reservations (and thereby need not remit state excise taxes ${ }^{3}$ ) or in low-tax, tobacco-producing states like North Carolina, Kentucky, or Virginia.

While these sites facilitate avoiding state excise taxes (which are usually collected from the wholesaler), they do not eliminate the legal obligation to pay them. ${ }^{4}$ By state law, an individual is supposed to pay the excise tax on any cigarettes they consume in their state of residence, even if the cigarettes are purchased elsewhere and brought into the state or received by mail. Like the use tax on mail order purchases, though, few people comply

As described in the existing GAO reports (2002; 2003), there is little states can do to curb online tax evasion. New York tried banning the delivery of cigarettes ordered online and began enforcing that ban in 2003 by threatening fines for delivery companies and by threatening to close down merchants within the state, many of which are operated on the Seneca Indian lands in upstate New York (Business Review, 2003). From May, 1999 to September, 2001 California notified 167 Internet vendors and 23,500 residents of their tax

\footnotetext{
${ }^{3}$ There are some states that have either laws or tribal compacts that call for the remittance of state taxes on reservation sales to non-tribal members. While the enforcement mechanisms differ across states that tax Native American Reservation sales, evasion is still thought to be extensive.

${ }^{4}$ The Jenkins Act, a federal law, requires anyone who sells cigarettes for a profit to a customer across state lines (other than to a licensed distributor) to report the brand and quantity of the sale as well as the name and address of the customer to the buyer's state's tobacco tax authority, but penalties for violation of this act are small and enforcement by the FBI has been limited.
} 
obligations, but collected only $\$ 1.4$ million in taxes, penalties, and interest (GAO, 2002). In 2005, the Attorney Generals of New York, California, and Oregon negotiated a deal with the major credit card companies to stop processing payments of Internet cigarette sales (Consumeraffairs.com, 2005), making the transactions more difficult. However, other forms of payment have proliferated, such as direct debit.

The federal government is also concerned about the issue. Congress has proposed legislation that would strengthen reporting requirements, raise violations of the Jenkins Act to a felony and reduce the number of cigarettes required to qualify as contraband from 60,000 10,000 (Judith Glasner, 2003). More recently, Congressman John M. McHugh (R-NY) introduced a bill that would outlaw the shipping of tobacco products by the U.S. Postal Service (Truman Lewis, 2007). Other mail carrier services already ban the shipping of tobacco products.

While online cigarette sales have garnered much interest from politicians and government agencies, there is little information on the most basic of issues, such as the volume of online cigarette sales. Robert Rubin (2001) predicted online sales of cigarettes would exceed $\$ 5$ billion by 2005, equal to about 14 percent of total sales and causing $\$ 1.4$ billion in lost tax revenue.

The Behavioral Risk Factor Surveillance System (BRFSS) data on cigarette usage that we will use below contains some further information on Internet cigarette sales. In 2003, the BRFSS included a question that asked whether smokers in Oregon had purchased cigarettes online or through the mail. More than 6 percent said yes (BRFSS Oregon, 2004). A second piece of indirect evidence comes from the frequency with which people use search engines to look for sites related to online cigarette sales. Using Overture's Keyword Selector Tool, we 
computed the number of searches conducted in March 2004 for terms associated with buying cigarettes online. ${ }^{5}$ The results indicate that at Overture, there were about 350,000 searches for the month (4.2 million at an annual rate) using the basic search definitions and 734,000 searches using a broader definition of the search terms (8.8 million annually). Scaling these numbers up by Overture's estimated market share implies that there are between 13 and 28 million searches per year for terms related to buying cigarettes online. ${ }^{6}$ We do not know how many of these searches turned into purchases nor how many searches a typical customer might do in a year, but these numbers likely understate the true magnitude if only because people who purchase online from a merchant may return directly to that merchant in the future rather than going back through the search engine. To be sure, such estimates are only suggestive. Virtually all expert observers agree, however, that online cigarette sales have been growing very rapidly in the last several years.

It is easy to understand why demand would be high for online cigarettes if most or all of the tax savings associated with online sales are passed on to consumers, rather than being captured by online merchants through higher pre-tax prices. To check this assertion, in the fall of 2003, we gathered data on in-store retail prices from several merchants in Ann Arbor, Michigan and compared them to the prices available at the top five domestic cigarette sites

\footnotetext{
${ }^{5}$ The Keyword Selector Tool is available at

http://inventory.overture.com/d/searchinventory/suggestion. The search terms we looked up were "cigs," "cheap cigarettes," "discount cigarettes," "cheap Marlboro," "discount Marlboro," "tax free cigarettes," "low price cigarettes," "cheapest cigarettes," "cigarettes online," "cigarettes price," "buy cigarettes," those same terms replacing the word "cigarettes" with "cigs" and also including the proposed variants suggested by the Keyword Selector Tool that referred to buying cigarettes online (the tool is designed to show other search terms that are similar to the one you enter that consumers also searched). We excluded anything that referred specifically to other countries or had nothing to do with buying online such as "current cigarette tax rate." For a broader definition of online buying we also tried including "cigarettes" alone as well as the brand names alone (like "Marlboro"), although these are not associated only with online buying.

${ }^{6}$ The search engine market shares come from Web Side Story (http://www.websidestory.com/pressroom/pressreleases.html?id=219\&ctl=x08x087h27h2) and assume that the Overture numbers represent all searches not included in the market shares of Google or Yahoo (the Yahoo market share statistics do not include Overture searches). This is obviously an upper bound for the size of Overture, so the calculation puts a lower bound on the total number of searches.
} 
listed at Google for the search phrase "tax free cigarettes." ${ }^{7}$ We analyzed the top ten cigarette brands, as identified by AdvertisingAge (2002). ${ }^{8}$ Weighting the ten brands by their national sales volume, we found that prices online were $\$ 27.33$ a carton when pre-tax prices in the stores were $\$ 25.83$. At that time Michigan taxes (including sales tax) amounted to $\$ 14.80$ per carton, so the average online site was apparently passing about 90 percent of the tax savings through to the consumer. So it seems clear that online sites are, indeed, a way for customers to evade local cigarette taxes to save money when buying cigarettes. If raising cigarette taxes induces consumers to seek out tax-free cigarettes, the rise of tax-free online cigarettes may well increase the price sensitivity of taxed sales. The remainder of this paper seeks to identify and quantify this effect empirically.

\section{Methodology and Data}

\section{A. Data}

We measure Internet penetration, defined as the share of households with internet access in a state, using large cross-sectional micro survey data that contain information on Internet use by respondents within a state for a given year.

Our primary data source is the computer supplements to the Current Population Survey (CPS) that asks respondents about Internet usage in 1989, 1993, 1997, 1998, 2000, 2001, and 2003. ${ }^{9}$ Unfortunately, the wording of the CPS survey questions we use changes from year to year. The 2001 and 2003 surveys inquire about Internet use from any location,

\footnotetext{
${ }^{7}$ The retail merchants were Walgreen, Meijer, K-Mart, Campus Corner, and Kroger. The online sites were taxfreecigarettes.com, travelingsmoke.com, dutyfreetaxfree.com, tobaccobymail.com and 4cheapcigs.com. All of these sites are located on Indian reservation land in New York State. An analysis using merchants in Chicago showed a similar pattern as the one reported in this paper.

${ }^{8}$ These brands were Marlboro, Newport, Doral, Camel, Basic, Winston, GPC, Kool, Salem, and Virginia Slims.

${ }^{9}$ The surveys take place late in the year, so we assign each year of Internet usage data to the fiscal year associated with the following year. To be consistent with the timing of the sales data, we define a fiscal year as running from July 1 of year $t-1$ to June 30 of year $t$.
} 
whereas in 1998 and 2000 the surveys ask about Internet usage in the home and outside the home separately. In 1997, the CPS survey asks for Internet usage at home, work, and school separately, whereas prior to 1997 the survey questions concern only whether the respondent uses a modem and has email. ${ }^{10}$ We define a respondent as connected to the Internet in 1997, 1998, 2000, 2001, and 2003 if she answers “yes” to any of that year’s Internet usage questions and in 1989 and 1993 if she responds that she has email or a computer with a modem. We then construct an Internet penetration measure by state and year consisting of the share of respondents in each state and year that were Internet connected.

Because the CPS Computer Supplements yield only seven years of data, we linearly interpolate the state-level Internet penetration rate between survey years to construct a continuous state-level panel from 1980 to 2005. Prior to fiscal year 1990, we assume Internet penetration is zero.

As a check on the CPS data, we also will use data from a large consumer survey conducted by Forrester Research, Inc. as part of the Technographics 2002 program. The survey collected demographic information from a nationally-representative sample of about 80,000 people and posed questions about whether they use the Internet at all, whether they have ever bought something online, and their past history of Internet usage. ${ }^{11}$ Using the responses to a question about how long each person has been online, we create a measure of the share of each state's population that was online in a given year from 1997 to the present,

${ }^{10}$ There is a 1994 CPS survey that asks only whether the respondent has a computer with a modem. We exclude this survey because the Internet penetration rate is much lower and is "off trend" when these data are used. However, we also run specifications in which we impute the 1994 Internet penetration rate by multiplying the share of modem users in 1994 by the share of modem users in 1997 that had Internet access (58 percent). Our results are not sensitive to the inclusion of the 1994 data in this manner.

${ }^{11}$ More details on the Forrester data can be found in Goolsbee (2000) and Steve Yonish et al. (2001). 
following the method of Goolsbee and Jeffrey Brown (2002). For years before 1997, we set the Forrester Internet use measures to zero.

The data on taxable cigarette sales, excise taxes, and the retail prices of cigarettes are taken from The Tax Burden on Tobacco, published by The Tobacco Institute until 1998 and updated by Orzechowski and Walker (2006). The tax rate we use is the weighted average of rates in effect over the fiscal year, adjusted to real 2005 dollars using the CPI. Because the retail price is only reported at a point in time (November 1 of each year), we impute an estimate of the average retail price over the fiscal year. ${ }^{12}$

When we examine how the difference between consumption and taxed sales in states responds to tax and price changes, we use data for 1990 to 2000 from the Center for Disease Control's Behavioral Risk Factor Surveillance System (BRFSS). These data provide information on the number of cigarettes smoked per day for people who report being smokers. The BRFSS is a large, nationally and state representative dataset that is meant to provide a comprehensive look at the risky behaviors of individuals in the United States. The data are collected annually from a random sample of adults (age 18 and over). ${ }^{13}$

Summary statistics for the variables used in our analysis for the years 1980, 1990 and 2000 are presented in Panel A of Table 1. This table shows clearly the sharp increase between 1990 and 2000 in real cigarette excise taxes and illustrates the rapid growth in Internet penetration over the sample period. For example, in the CPS data, only 5 percent of respondents had online access in 1990, and by 2000 the penetration rate had increased to 40 percent. As of 2005, the same measure shows over 63 percent of the sample had access to the

\footnotetext{
12 To do this imputation, we assume constant linear growth from November to November of each year. Given this assumption and prices from the previous and following years, the formula for the average price in the year is $\mathrm{P}=10 / 144\left(\mathrm{P}_{\mathrm{Nov}, \mathrm{t}-1}\right)+106 / 144\left(\mathrm{P}_{\mathrm{Nov}, \mathrm{t}}\right)+28 / 144\left(\mathrm{P}_{\mathrm{Nov}, t+1}\right)$. Our results were similar using the listed November spot price instead of the imputed price.

${ }^{13}$ More details on the BRFSS can be found in Center for Disease Control (2003).
} 
Internet. For Internet penetration, most of the variation comes across time, although the variation in Internet usage across states within a year is non-trivial.

\section{[Approximate location of Table 1]}

\section{B. Empirical Methodology}

We investigate whether the level and tax responsiveness of a state's taxable cigarette sales (denote $q$ below) are related to the extent of Internet use in that state (denoted with a subscript $i$ below) in a given year (denoted with a subscript $s$ ). Because, we presume, online cigarette sales are driven mostly by tax evasion, and because tax changes at the state level are more plausibly exogenous than wholesale price variation, we analyze the effects of wholesale price and tax changes separately in our empirical specification. ${ }^{14}$

To identify the effect of changes in the cigarette tax rate on cigarette sales in the presence of Internet smuggling, we regress the logarithm of per-capita taxable cigarette packs sold in the state $\left(\ln \left(q_{i s}\right)\right)$ on the log of the real excise tax of cigarettes in the state $\left(\ln \left(t_{i s}\right)\right)$, the $\log$ real wholesale price of cigarettes in the state $\left(\ln \left(p_{i s}\right)\right)$, a measure of neighboring states' tax-inclusive prices, and real per-capita state income. ${ }^{15}$ Then, we add an interaction of our measure of Internet penetration with the state’s $\log \operatorname{tax}^{16}$ The basic specification is

\footnotetext{
${ }^{14}$ While we include the wholesale price in our regressions, we stress that putting a causal interpretation on its estimated coefficient is problematic because the variation in wholesale prices within states over time is likely at least partially due to jointly-determined demand and supply factors. In contrast, the variation in state excise taxes is driven largely by the need for tax revenue (Advisory Commission on Intergovernmental Relations (ACIR), 1985). Our results and conclusions are robust to excluding wholesale prices from the analysis, but we nonetheless include them in all regressions as these results remain of interest, despite the difficulty of interpretation.

${ }^{15}$ Another way to model prices in equation (1) would be to control for $\ln (p)$ and $\ln (1+t / p)$ separately. The advantage of such a specification is that $\ln (p)+\ln (1+t / p)=\ln (p+t)$. However, in order to separately identify the effect of Internet penetration on taxable sales elasticities, one must instrument $\ln (1+t / p)$ with state-level excise taxes. We explored such specifications in earlier versions of this paper and they give similar results to those obtained from estimating equation (1). We prefer the specification as written in equation (1) because it provides a simple way in which to identify Internet penetration effects on the responsiveness of taxable cigarette sales to taxes.

${ }^{16}$ Notably, equation (1) excludes an interaction between $\ln (p)$ and $I$. We exclude this interaction because of concerns that the residual wholesale price variation is endogenous. If $\ln (p)$ is endogenous, interacting
} 


$$
\begin{aligned}
\ln \left(q_{i s}\right)= & \beta_{0}+\beta_{1} \ln \left(t_{i s}\right)+\beta_{2} \ln \left(t_{i s}\right) * I_{i s}+\beta_{3} \ln \left(p_{i s}\right)+\beta_{4} I_{i s}+\beta_{5} \ln \left(p^{N}+t^{N}\right) \\
& +\beta_{6} Y_{i s}+\phi_{s}+\eta_{i}+\delta_{i} * s+\varepsilon_{i s},
\end{aligned}
$$

where $I_{\text {is }}$ is a measure of the Internet penetration rate in the state, $\ln \left(p^{N}+t^{N}\right)^{17}$ is the $\log$ average real tax-inclusive price of all border states weighted by the population of each border state, ${ }^{18}$ and $Y_{i s}$ is $\log$ real personal income per capita in the state. In order to make our results reflective of the average across individuals rather than the average across states, all regressions are weighted by state-by-year populations, taken from the U.S. Census Bureau.

We do not expect to be able to explain all of the cross-state and cross-time variation in taxed sales due to non-tax factors, so in equation (1) we also include dummy variables for each state and each year as well as state-specific linear time trends that control for cross-state heterogeneity in secular sales trends over time. Allowing for state-specific time trends as well as state fixed effects is important because both the level and trend of sales likely are correlated with anti-smoking sentiment within a state. These changes can be spuriously attributed to changes in smoking behavior due tax variation, especially if tax changes move with changes in a state's anti-smoking sentiment.

By including as independent variables state and year dummy variables as well as statespecific linear time trends, we are seeking to explain breaks from each state's linear time trend in sales associated with changes in the state tax rate of cigarettes, and in particular whether the tax sensitivity has increased most in states where Internet penetration has grown

it with $I$ can bias the coefficient on the log tax and Internet term. While we exclude this term from the main specification shown in the paper, the results are robust to including $\ln (p) * I$. Our results also are robust to excluding $\ln (p)$ altogether.

${ }^{17}$ While we include $\ln (p)$ and $\ln (t)$ separately in equation (1), we do not separate neighbors' average taxes and wholesale prices. Instead, we control for neighbors' average tax-inclusive price because, unlike Internet smuggling, we expect consumers to respond to neighboring states' taxes and wholesale prices similarly, conditional on their home state taxes and prices.

${ }^{18}$ Due to potential endogeneity of border prices, we instrument real border state average prices with real border state average taxes in all specifications. 
the fastest. ${ }^{19}$ However, because we linearly interpolate Internet penetration rates in each state post-1989, the state-specific linear time trends are mostly identified off of pre-1990 sales trends, as the post-1989 linear time trends and Internet penetration rates are highly collinear. The implicit identifying assumption in this setup is that pre-1990 trends are an accurate counterfactual for the post-1990 secular trends in per-capita state cigarette sales.

A principal goal of our empirical analysis is to determine whether the rise of Internet availability of untaxed cigarettes increases the responsiveness of taxable sales to the tax rate. A negative value of $\beta_{2}$ in equation (1) will indicate such a causal link between Internet connectivity and sales elasticities. Interpreting $\beta_{2}$ as the causal effect of Internet penetration on tax elasticities is incorrect if Internet penetration is correlated with underlying trends in tax elasticities over time. If Internet penetration rates grow faster in states that were, for other reasons, experiencing larger growth in the tax-responsiveness of sales, we might estimate a negative value of $\beta_{2}$ in equation (1), but it would be due to spurious correlation of Internet penetration rates and per-capita cigarette sales at the state level not captured by our control variables (including the state-specific linear time trends) and would have nothing to do with smuggling.

We examine whether changes in state-level Internet penetration rates are correlated with Internet-unrelated trends in state-level tax responsiveness by estimating a version of equation (1) separately for the pre-Internet period (1980-1989) and the Internet period (19902005), excluding all Internet terms but including state-specific tax rate and wholesale price terms as well as linear state-specific tax rate and wholesale price elasticity trends. If the post-

\footnotetext{
${ }^{19}$ We ignore the possibility that the extent of Internet use is itself affected by the level of cigarette taxes in a state and therefore the potential tax savings from using the Internet to avoid or evade taxes. Goolsbee (2000) showed that our presumption is true for the case of retail sales taxes, and cigarette taxes are even less likely to motivate people to go online since the amount of money at stake is typically smaller.
} 
1990 Internet penetration rates are related to pre-Internet-era (and therefore Internetunrelated) tax elasticity trends, we should observe this relationship in Figure 1, which graphs the estimated state-specific tax rate elasticity trends in the two periods as a function of the 2005 Internet penetration rate. Panel A of Figure 1 shows the point estimates from the preInternet period and Panel B shows point estimates from the period that includes Internet growth. The size of each point in the Figure reflects the average population over the sample period in the state. Each panel also shows a best-fitting linear relationship. Panel A illustrates that there is no significant negative relationship between the state-specific taxed sales elasticity trend from the period 1980-1989 and 2005 Internet penetration rates; ${ }^{20}$ indeed, the relationship is positive and significantly different from zero at the 10 percent level. In contrast, there is a negative and sizeable relationship (significant at the 9 percent level) between Internet penetration rates and state-specific taxable sales elasticity trends estimated for the post-1989 period. Thus, trends in state-specific taxable sales elasticities are negatively correlated with Internet penetration rates only for the period in which there was Internet growth. In the pre-Internet period, the state-level variation in the trend of taxable sales elasticities is not correlated with state-level variation in future Internet penetration rates.

\section{[Approximate location of Figure 1]}

We explore further the relationship between Internet penetration rates and tax elasticities by estimating a similar model that replaces the state-specific tax interactions with year-specific tax interactions. In Figure 2, we present the estimated year-specific tax elasticities plotted against population-weighted average Internet penetration rates for the U.S. as a whole. All tax elasticities are calculated relative to the elasticity in 1980. Figure 2 shows

\footnotetext{
${ }^{20}$ Recall that, because there is no Internet use prior to 1990, the 2005 Internet penetration rate reflects the rate of Internet penetration growth between 1990 and 2005.
} 
that the time pattern of reductions in taxable sales elasticities corresponded closely with the timing of Internet growth. In fact, it was only after the Internet growth began in the mid-1990s and 2000s that taxable sales elasticities started to decline, i.e., became larger in absolute value. $^{21}$

\section{[Approximate location of Figure 2]}

Taken together, Figures 1 and 2 present supporting evidence that state-level variation in the growth in Internet penetration is uncorrelated with variation in the tax responsiveness of state cigarette demand other than through the effect of the Internet on facilitating tax evasion. There is no evidence in these figures that state-specific trends or shocks correlated with cigarette demand drove the differential growth in Internet penetration in the 1990s and 2000s. ${ }^{22}$ Throughout the analysis, we interpret $\beta_{2}$ as the causal effect of Internet smuggling on taxable sales elasticities. In Section V, we show this interpretation and our results are robust to a number of alternative specifications, including controlling directly for statespecific trends in taxable sales elasticities.

A second concern with identifying the effect of Internet smuggling on taxable sales elasticities using equation (1) is that if the equation is mis-specified, a correlation between tax rates and Internet penetration can cause the estimate of $\beta_{2}$ to be negative, even in the absence

${ }^{21}$ We also estimated a version of equation (1) that excluded the Internet interaction terms but included dummy variables for each 5-year block from 1980 to 2005 interacted with the log cigarette excise tax. Consistent with Figure 2, these estimates show it is in the time period of the highest Internet growth that taxable sales elasticities increased (in absolute value) the most relative to the early 1980s. Results are available upon request.

${ }^{22}$ We also have run "false experiments" examining whether per-capita beer sales became more excisetax-elastic in states that experienced higher growth in Internet penetration. These false experiments test whether differential Internet penetration rates are correlated with sin-tax responsiveness in general, or whether they are only correlated with cigarette-tax-responsiveness by increasing the availability of tax-free cigarettes. Using alcohol sales data from the National Institute of Alcohol Abuse and Alcoholism from 1980-2003 as described in Raj Chetty, Adam Looney and Kory Kroft (Forthcoming) and beer taxes per gallon taken from the World Tax Database at the University of Michigan, we estimate a coefficient on the log beer tax - Internet penetration rate interaction equal to 0.061 (the "wrong” sign), with a standard error of 0.458 . Our estimates do not support the hypothesis of a general trend in sin-tax responsiveness correlated with Internet penetration rates; details are available from the authors upon request. 
of Internet smuggling. For example, if states respond to increased Internet penetration by increasing their cigarette excise taxes, a given increase in Internet penetration can cause a reduction in sales, but not because smuggling has increased. Rather, the sales reduction occurs because taxes have increased. Note that, because we control directly for tax rates and Internet penetration, this correlation only will bias our estimate of $\beta_{2}$ if equation (1) is mis-specified.

This concern is mitigated by the fact that any correlation between $\ln (t)$ and $I$ is likely to be negative, because states may combat Internet smuggling by not raising taxes. To the extent such a correlation biases our results, it is likely to attenuate our estimate of $\beta_{2}$. We find no evidence in the data, however, that tax changes and Internet penetration rates are correlated. Table 1 presents some descriptive statistics regarding the size and frequency of tax changes over our sample period. As Panel A of Table 1 illustrates, there are a total of 192 nominal state excise tax changes over the sample period: 69 occurred between 1980 and 1989, 71 occurred between 1990 and 1999 and 52 occurred between 2000 and 2005. Furthermore, the growth in log excise taxes in each decade increased, with an average increase between 2001 and 2005 over 3 times the average increase from 1980 to 1989. These tabulations reflect the increasing size and frequency of excise tax changes over the period 1980 to 2005, as cigarette taxes gained in popularity.

Panels B and C of Table 1 give sample means and tax and Internet penetration changes separately for the top and bottom 10 Internet penetration states as of $2005 .{ }^{23}$ A comparison of these two panels reveals that average log per capita cigarette sales were slightly lower in the high Internet growth states in 1980 and fell by about the same amount as in the lower Internet

\footnotetext{
${ }^{23}$ The top 10 Internet penetration localities in 2005 were Connecticut, Minnesota, Nebraska, New Hampshire, Utah, Washington, Arizona, Colorado, Washington DC, and Wyoming. The bottom 10 states were Alabama, Arkansas, Louisiana, Mississippi, New Mexico, West Virginia, Kentucky, New York, South Carolina, and Texas.
} 
penetration states. In states with high Internet penetration, cigarette taxes were higher in 1980 and grew noticeably more rapidly than in low Internet penetration states. However, neither the differential timing of tax changes nor the tax change magnitudes are correlated with Internet growth. To illustrate this last point, we split the data into three time periods: 1991-1995, 1996-2000, and 2001-2005. In each period and for each state, we calculated the number of excise tax changes, the change in log excise taxes, and the change in Internet penetration rates. Within each period, we ran Poisson regressions and OLS regressions of the number of tax changes and the change in log excise tax levels, respectively, on the change in Internet penetration. There is no statistically significant evidence that either the number of tax changes or the size of tax changes is correlated with Internet growth within each period. These regressions suggest the short-run state-level variation in excise taxes we use to identify $\beta_{2}$ is uncorrelated with Internet penetration rates; even if equation (1) is mis-specified, it will correctly estimate the impact of Internet smuggling on cigarette sales elasticities.

The cigarette sales elasticities of interest come directly from equation (1). Throughout this analysis, we are interested in the tax rate elasticity of taxable sales, which is the percent change in taxable sales when the excise tax rate changes by one percent, holding Internet penetration constant. From equation (1), the tax elasticity is

$$
\varepsilon^{t}=\frac{\partial \ln (q)}{\partial t}=\beta_{1}+\beta_{2} * I
$$

A negative value of $\beta_{2}$ indicates that increasing Internet access increases the magnitude of the (negative) response of sales to tax changes - an effect consistent with Internet smuggling. Note that the elasticity with respect to the tax rate is easily converted into a price elasticity (due to a tax rate change) by multiplying $\varepsilon^{t}$ by $\frac{p+t}{t}$, which in 2000 was 7.43 . 
The taxed sales elasticity absent the Internet is $\beta_{1}$. This elasticity gives the percent change in taxable sales assuming no Internet smuggling occurs and shows the potential for cigarette prices to alter smoking behavior in the absence of smuggling.

\section{Results}

\section{A. Coefficient Estimates}

The coefficient estimates from equation (1) are presented in Table 2. Column (i) presents baseline estimates that exclude Internet penetration. This is a specification analogous to those in the existing literature, and the magnitude of the estimated tax rate elasticity is similar to price elasticities from tax changes presented in recent studies analyzing a similar time period (Stehr, 2005). While the estimated coefficient on log wholesale prices is positive, it is not statistically significant at even the 10 percent level.

In column (ii), we add our CPS measure of Internet penetration to the regression in order to estimate how the effect of tax changes on taxable sales depends on the extent of Internet use. Our results indicate that Internet penetration makes taxed sales more tax-rate elastic; the estimated coefficient on the tax rate-Internet interaction is -0.192 and is statistically significant at the 5 percent level. This estimate suggests the tax rate elasticity of taxable sales is highly responsive to Internet penetration: in the extreme, increasing Internet availability from 0 to 50 percent nearly doubles the taxable sales elasticity.

\section{[Approximate location of Table 2]}

As expected, the elasticity with respect to real per-capita income is positive and significant, but less than one. The point estimate of the elasticity of taxable sales with respect 
to the mean tax-inclusive price of neighboring states is essentially zero, and it is not statistically significant. ${ }^{24}$

The estimated coefficient on the Internet term is 1.008 which, combined with the 0.192 estimated coefficient on the $\ln (t) * I$ interaction term, implies that more Internet access both makes the demand curve for taxed sales more elastic and pushes it out for all but the highest observed tax rates. One explanation for this finding is that Internet access increases both taxed and non-taxed sales by implicitly lowering cigarette prices. However, this explanation is unlikely given the magnitude of the estimated effect. A more mechanical explanation is suggested by the sharp drop-off in estimated year effects beginning in 1999, just the time when our measure of Internet access begins growing most rapidly. Without a large positive coefficient on I, our specification cannot explain why Internet access increases the taxed sales elasticity without also decreasing taxed sales beginning in 1999. To investigate this possible explanation, column (iii) shows the results of estimating the same specification as in column (ii), but without the fixed year effects. The central qualitative result is unchanged: Internet access increases the elasticity of taxed sales with respect to the tax rate, although the magnitude of the interaction term is only about three-quarters the estimated effect in column (ii). Notably, the estimated coefficient on the Internet term is about half its magnitude in column (ii), so that the column (iii) results imply that increased Internet access both increases the elasticity of taxed sales to tax rates and reduces taxed sales, as long as the

\footnotetext{
${ }^{24}$ Because of the importance of controlling for cross-border effects due to the possible substitution between cross-border shopping and online shopping, we also estimated regression specifications that included an indicator for whether any border state has a lower tax, whether any border state has a higher tax, the minimum and maximum border taxes, and interactions between the indicator variables and the minimum and maximum tax rate. The coefficient on the $\ln (t) *$ Internet term in the regression that includes all of these cross-border measures is -0.209 (0.075), which is comparable to the estimate in Table 2, column (ii). We also performed regressions using these border tax measures separately, and found similar results. While our baseline specification uses the average border price/tax measure, our results are robust to controlling for a variety of non-linear relationships between border-state tax rates and sales.
} 
tax rate exceeds 35.1 cents $\left(\mathrm{e}^{(.484 / .136)}\right)$. Although this arguably is a more plausible story, we are wary of dropping the fixed year effects because of their ability to account for otherwise unexplained, non-linear changes in the demand for taxed sales. For that reason, in what follows we retain the fixed year effects. As shown in column (iii), however, an alternative reasonable specification implies the same qualitative, but a somewhat smaller quantitative, effect of Internet access on the elasticity of taxed sales.

The remaining four columns of Table 2 show results from estimation of equation (1) using differing Internet access measures and years. In column (iv) we use the Internet penetration rate from Forrester, ${ }^{25}$ and while some of the other coefficients vary, the coefficient on the Internet-tax term interaction is negative, significant and of roughly similar magnitude to the baseline estimate.

Columns (v) and (vi) deal with the issue of imputed values. Column (v) restricts the sample to only those years where Internet usage is positive (i.e., with no imputed zeros) by looking only at the years after $1989 .{ }^{26}$ Column (vii) uses only years in which the CPS actually has observations (i.e., there is no imputed Internet usage between survey years). In both specifications, the estimated main effects are larger in absolute value than in the cases

\footnotetext{
${ }^{25}$ Note that the Forrester data we have extend to 2002 rather than 2005. Furthermore, because of the limitations of the survey question, all Internet penetration is set to zero prior to 1997. That the results change little when these restrictions are imposed implies that most of the identification of the estimated Internet-price effects is coming from years in which Internet penetration was growing at the fastest rate.

${ }^{26}$ Because the Internet penetration rates grow close to linearly within each state, the state-specific linear year trends post-1989 and the Internet penetration rates are highly collinear. Thus, we exclude the state-specific linear trends in the estimates reported in columns (vi) and (vii). In results not reported, we have run specifications in which we created dummy variables for each 5-year block from 1980-2005 and included period block by state fixed effects (but not state-specific linear time trends). Results in all columns of Table 2 are affected negligibly, which suggests excluding the state-specific time trends in the post-1989 specifications is not biasing our results. Estimates from these regressions are available from the authors upon request.
} 
using imputed values in the full panel data set, suggesting that our results are not driven by our imputation of the Internet penetration rate. ${ }^{27}$

\section{B. Elasticity Estimates}

While the coefficients in Table 2 give insight into the effect of the Internet on taxable sales and tax responsiveness, the parameter of most interest to policy makers is the tax rate elasticity of taxed sales. Table 3 shows the average elasticity estimates for fiscal year 2000 implied by the results in Table 2. The first row shows the tax elasticity in the presence of Internet smuggling (equation (2)), and the second row shows the tax elasticity assuming Internet use is zero. This latter elasticity is the tax elasticity of sales in the absence of smuggling and is the elasticity much of the previous literature seeks to estimate. ${ }^{28}$ The bottom two rows of Table 3 show the difference in the elasticities and the P-value of the test that sales are more tax-responsive in the presence of the Internet. We calculate P-values using 10,000 bootstrap replications of the data, clustered at the state-level. The P-value represents the proportion of replications in which the elasticity with the Internet is smaller in absolute value than the elasticity without the Internet. A P-value less than 0.05 signifies one cannot reject that the Internet-inclusive elasticity is larger in absolute value then the elasticity assuming no Internet connectivity at the 5 percent level. Because the tax rate elasticity is a function of the Internet penetration rate (see equation (2)), our bootstrap test accounts for both the sampling variability of the Internet penetration rate as well as the precision of the estimate of $\beta_{2}$.

\footnotetext{
${ }^{27}$ Similar to results in column (v), we exclude the state-specific linear time trends because they are highly collinear with Internet penetration. Results in column (vi) are robust to including 5-year period-by-state fixed effects, however.

${ }^{28}$ See Lovenheim (2008) for a discussion of the different definitions of consumption and sales elasticities and their relevance for tax policy analysis.
} 
Across columns (ii)-(vi) in Table 3, the results suggest that sales can be quite elastic with respect to state cigarette taxes in the presence of Internet smuggling: the tax rate elasticities range from -0.186 to -0.267 . If no Internet smuggling occurred, sales are less elastic with respect to tax changes; the estimate in column (ii) is indicative at -0.112 . To obtain the price elasticity associated with tax changes, one must multiply the tax elasticity by 7.43 (i.e., $\frac{p+t}{t}$ ), which yields -0.832 . This responsiveness is at the upper end (in absolute value) of elasticities reported in the literature, ${ }^{29}$ but is consistent with more recent estimates from the period before the steep increase in Internet penetration in the U.S. (Yurekli and Zhang, 2000; Keeler et al., 2001). Table 3 illustrates that, by 2000, the availability of the Internet had increased the state excise tax rate elasticity by 69 percent, and this increase is statistically significant in all columns.

\section{[Approximate location of Table 3]}

That increases in Internet penetration increase the sensitivity of taxed sales to statelevel cigarette taxes suggests that specifications that ignore Internet usage over this period will produce price elasticity estimates with respect to tax rate changes that are between the elasticity estimates with and without Internet smuggling shown in Table 3. Column (i) in Table 3 presents elasticity estimates from our baseline model that ignores Internet usage. The results are consistent with this prediction; the tax rate elasticity in the baseline model is -0.171 (with a corresponding price elasticity of -1.271), which is much larger than the corresponding tax rate elasticity in column (ii) that includes Internet smuggling but smaller than the tax rate elasticity in column (ii) without Internet smuggling. These results suggest that models that ignore Internet smuggling identify neither the tax rate elasticity that includes Internet

\footnotetext{
${ }^{29}$ In their review of the literature, Chaloupka and Warner (2000) report price elasticities typically fall within a small neighborhood of -0.4 .
} 
smuggling (which is the relevant policy parameter from the state's perspective) nor the tax rate elasticity if Internet smuggling were eradicated.

The estimated baseline taxable sales elasticity shown in column (i) is much higher in absolute value than those from the previous literature as well. This difference in part reflects a rise in taxable sales elasticities that are due to the secular rise in Internet smuggling . For example, Yurekli and Zhang (2000) find a taxable sales elasticity with respect to price of 0.72 over the period 1970-1995, and Stehr (2005) finds a taxable sales elasticity of -1.11 over the period 1985-2001. This change also is reflected in Figure 2, which shows that the taxable sales elasticity with respect to state tax rates has increased markedly since the 1980s. Although the estimated taxable sales elasticity is rising over time, the elasticities absent smuggling in Table 3 are quite similar to estimates from the 1980’s and early 1990's (before the large rise in Internet use), which suggests this increase can be explained largely by the rise of Internet smuggling.

\section{Implied Revenue Effects}

Our estimates from Tables 2 and 3 imply that Internet smuggling has changed the relationship between state tax rates and taxed sales and that the Internet has reduced the revenue gains that otherwise would have been collected from recent cigarette tax increases. From the baseline estimates in column (ii) in Tables 2 and 3, we can estimate the impact of Internet sales on the revenue gained due to tax increases between 2001 and 2005, which was a period of substantial cigarette tax increases in the United States. Over this period, populationweighted average real per-pack cigarette taxes increased from 74.9 cents to 105.7 cents nationally, a 41 percent increase. Using the price elasticity due to a tax change calculated from the tax rate elasticities in Table 3, column (ii), this increase implies that average tax 
revenues increased by 9.0 percent less than would have been expected without any tax-free Internet sales. $^{30}$

The estimates of revenue effects vary across states and time. Using our estimates from New Jersey, where, over this period, real taxes rose from 110.4 to 278.1 cents per pack and Internet penetration rose from 49.9 to 64.8 percent between 2001 and 2005, we estimate that absent Internet purchases revenues would have increased by over 135 percent but actually increased by 116 percent, representing a drop in expected revenues of over 14 percent. In contrast, in a state such as Louisiana, where Internet usage was only 29.7 percent in 2000, our estimates suggest tax-free Internet sales reduced the revenue effect of tax increases by only 6.9 percent. In short, our findings suggest that due to Internet smuggling, states have experienced a significant reduction in their ability to raise money through tobacco taxes.

\section{Cigarette Consumption and Internet Smuggling}

To investigate the relationship among cigarette consumption, Internet smuggling, and cigarette taxes, we turn to the BRFSS data on individual cigarette consumption. Using these consumption data, we construct state-level measures of annual packs-per-person smoked. ${ }^{31}$ If the increased taxed sales elasticities associated with increased Internet penetration are due to

${ }^{30}$ To calculate the estimated effect of Internet smuggling on revenues, we calculate the percent change in the revenue elasticities due to Internet penetration. The revenue elasticities are given by $\left(1+\varepsilon^{t}\right)$. The taxable sales elasticity with respect to the tax rate that includes Internet penetration is found in the first row of column (ii), Table 3. The taxable sales elasticity with respect to the tax rate that assumes no Internet purchases is found in the second row of column (ii), Table 3. The percent decrease in the increased revenue from a tax rate increase because of increased Internet use is given by the percentage change in revenue elasticities:

$$
\frac{\varepsilon^{t}-\varepsilon_{n o I}^{t}}{\left(1+\varepsilon_{t}\right)}=\frac{-.192+.112}{0.888}=-0.090 \text {. }
$$

${ }^{31}$ The CPS Tobacco Supplements, based on surveys conducted in 1993, 1996, 1999 and 2002, also contain cigarette consumption information. Although the CPS contains data to 2002 and the BRFSS spans 1990 to 2000, the latter data set is continuous throughout these years and the former only contains 4 years of data. We therefore use the BRFSS consumption data in this analysis, but results using the CPS data are qualitatively similar to what we report here, although they are less precise due to a smaller sample size. 
smuggling, we expect there to be no negative relationship between Internet penetration rates and the consumption responsiveness to tax increases.

To test whether the increased tax-responsiveness of sales is associated with a similar increase in responsiveness of consumption, we first estimate equation (1) using the log percapita cigarette consumption measure from the BRFSS as the dependent variable. The results, reported in Table 4, show no statistically significant evidence of differential consumption elasticities by Internet penetration rates. These estimates are consistent with the explanation for the recent changes in the taxed sales elasticity being due to smuggling behavior rather than a consumption response.

\section{[Approximate location of Table 4]}

Absent smuggling (or any other reason for untaxed cigarette consumption), the BRFSS annualized per-capita smoking level and per-capita taxable sales should be equal in each state-year observation. We therefore can construct a measure of smuggled cigarettes by taking the difference between log state-level cigarette consumption and log state-level taxed sales. ${ }^{32}$ In columns (iv)-(vi) of Table 4, we present results from regressions analogous to equation (1) that use this dependent variable. The expectation is that the difference between log consumption and log taxed sales should respond positively to increases in home state prices and that increased Internet access should increase the magnitude of this response, because taxable sales respond more to tax rate changes than does consumption when Internet access is higher.

The results in Table 4 are consistent with these expectations. Looking at column (iv), the coefficients on the tax variables are both positive, although only the coefficient on the tax

\footnotetext{
32 Stehr (2005) uses an identical measure to estimate the level of casual smuggling and bootlegging. He does not provide estimates of cigarette smuggling over the Internet.
} 
rate is significant at the 5 percent level. These estimates are suggestive that the difference between cigarette consumption and cigarette sales responds positively to the tax rate.

Moreover, this difference responds more positively to tax changes the higher is the Internet penetration rate, although the tax-Internet interaction coefficient is only significant at the 5 percent level in column (v).

\section{Robustness Checks}

Our results suggest that as Internet use grew in states, the sensitivity of taxable sales to price changes in those states grew as well. In Table 5, we consider whether this evidence is consistent with alternative explanations rather than being tied to a rise in cigarette smuggling due to the Internet.

\section{[Approximate location of Table 5]}

In column (i) of Table 5, we exclude the four states with the lowest cigarette taxes (VA, KY, NC, SC); because they are the source of a significant fraction of cigarettes sold through the Internet, taxable sales in these states might conceivably respond differently to changes in Internet usage. However, in part because they are only a small portion of the sample, the point estimates do not change appreciably when they are excluded.

In columns (ii) and (iii) we consider the role of Native American Reservations as an alternative source of smuggling. As detailed in Evans et al. (2002), a loosening of the rules regarding gambling on reservation land in 1989 caused a dramatic increase in the number of Indian casinos in the United States. To the extent that post-1989 more people frequented such casinos and while there were able to purchase cigarettes tax free, this would have made taxed sales more sensitive to tax rates due to tax avoidance, but the increased sensitivity will be only spuriously correlated with the growth of Internet-related tax avoidance over the same time 
period. To investigate the importance of this development, we split our sample based on the number of Indian casinos in each state in 2004 using data from the National Indian Gaming Association and estimate equation (1) using only states where there were 5 or fewer casinos (column (ii)) and only states with more than 5 casinos (i.e., the upper quartile of the casino distribution) in column (iii). The results suggest tax elasticities have increased due to the Internet for both sets of states.

The final two columns of Table 5 explore the importance of casual smuggling through cross-border shopping. Lovenheim (2008, Table 8) presents estimates of the proportion of cigarettes in each state purchased in lower-price localities. We classify a state as "high smuggling" if over 15 percent of consumed cigarettes are smuggled and otherwise as a "low smuggling” state. Columns (iv) and (v) in Table 5 report regression results from equation (1) estimated separately for these two groups of states. The coefficients on the log tax-Internet interaction terms are similar both to each other and to estimates from Table 2, suggesting that the extent of casual smuggling is not confounding our estimates.

In Table 6, we next consider the role of changing state demographics that are not accounted for by our extensive set of controls. First, in column (i) we allow the baseline elasticities to differ across states by interacting the state fixed effects with the price terms. In column (ii), we examine whether the Internet effect can be differentiated from a linear trend in the elasticity that applies to all states by adding an explanatory variable that interacts the log of each price with a linear year trend. The results from columns (i) and (ii) are consistent with the baseline estimates from column (ii) of Table 2, although the estimated effect of Internet penetration on tax rate elasticities is somewhat larger than the baseline estimates in column (i) and somewhat smaller than in column (ii). In column (iii), we combine the two 
previous specifications by including state-specific elasticities and linear year trends in prices. This specification examines whether higher Internet use makes states more price-sensitive than they would otherwise have been and accounts for any state-level heterogeneity in price sensitivity as well as secular national price trends. The results from column (iii) are similar in sign, magnitude and significance to those from Table 2.

\section{[Approximate location of Table 6]}

In column (iv), we include an aggregate measure of Internet connectivity in the U.S. as well as an elasticity trend. This specification forces the variation in Internet connectivity to be relative to the yearly average and nets out any year-specific Internet growth effects. The coefficient on the U.S. Internet penetration rate is positive, although not significant, and the coefficient on $\ln (t) *$ Internet is similar to those reported in Table 2.

Finally, in column (v), we allow for state-specific elasticities and state-specific elasticity trends, which are estimated by a triple interaction between state indicators, $\ln (t)$, and a linear year trend. Here, the coefficient on the tax rate-Internet variable is negative, significant, and of a similar magnitude to the baseline specification. Because this specification restricts the effect of the Internet to be relative to state-specific trends in tax elasticities, that the negative relationship between tax responsiveness and Internet penetration persists is suggestive that our empirical estimates are not simply picking up differential unobserved trends in tax elasticities correlated with Internet penetration rates.

\section{Conclusion}

Using information on the purchases of cigarettes and the use of the Internet across states and time since 1980, this paper has presented evidence suggesting that the rise of the Internet and the associated increase in the ability of individuals to purchase tax-free cigarettes 
has significantly increased the tax sensitivity of consumers. Our estimates imply the growth in Internet penetration in the U.S. led to a substantial increase in the taxable sales elasticity between 1990 and 2005. The evidence suggests this increased sensitivity is due to tax-free Internet sales and not due to any greater sensitivity of cigarette consumption. Our estimates imply that the ability of states to raise revenue by increasing the cigarette tax has been significantly compromised by the availability of tax-free cigarette purchases over the Internet. States are, however, far from the point where further tax increases would raise no revenue. Our results suggest this would not occur even when Internet penetration reaches 100 percent. Higher excise tax rate elasticities suggest that the deadweight loss per dollar of revenue collected has risen in the Internet era, and therefore these taxes are less attractive than otherwise. Two other policy considerations are, however, relevant. The first is that these elasticities are not immutable to tax system policy parameters and, as suggested by Joel Slemrod and Wojciech Kopczuk (2002), depend not only on the elasticity of substitution between cigarettes and other goods but also on the technology of tax evasion and tax enforcement as well as the interplay between the two. Thus, a consideration of the optimal state tax treatment of cigarettes should address not only the tax rate but also the enforcement of tax evasion and avoidance, be it through the Internet, casual smuggling, or organized bootlegging. In other words, the state need not passively accept the tax rate elasticity but can influence it via the measures it takes to combat evasion; whether such measures should be taken can be analyzed using the same kind of optimal tax analysis usually applied to tax rates and, sometimes, to tax bases. Indeed, Slemrod and Kopczuk (2002) suggest there is an optimal elasticity set by the non-rate tax system policy parameters. 
Finally, as in all aspects of state tax policy, there are cross-state fiscal spillovers, so that policy — and in particular enforcement policy - that is optimal from each state's point of view will generally be sub-optimal from the country’s perspective. These spillovers suggest that federal policy may have an important role in optimal cigarette excise tax policy. 


\section{REFERENCES}

AdvertisingAge. 2002. "Top 10 Cigarette Brands," June 24.

http://www.adage.com/page.cms?pageId=925.

Advisory Commission on Intergovernmental Relations. 1985. Cigarette Tax Evasion: A Second Look. Washington, D.C..

Becker, Gary, Michael Grossman, and Kevin Murphy. 1994. "An Empirical Analysis of Cigarette Addiction." American Economic Review, 84(3), June, 396-418.

Behavioral Risk Factor Survey System, Oregon. 2004. “Tobacco Use Module,” http://www.dhs.state.or.us/dhs/ph/chs/brfs/04/tobacco.pdf, page 28.

Business Review. 2003. "New York Begins Ban on Internet Sales," June 18. http://albany.bizjournals.com/albany/stories/2003/06/16/daily25.html.

Centers for Disease Control. 2003. "Behavioral Risk Factor Surveillance System." http://www.cdc.gov/brfss/index.htm (accessed October 2, 2003).

Chaloupka, Frank J. and Kenneth Warner. 2000. "The Economics of Smoking." In The Handbook of Health Economics, v.1B, ed. Joseph P. Newhouse and Anthony J. Culyer, 1539-1627. Amsterdam: Elsevier.

Chetty, Raj, Adam Looney and Kory Kroft. Forthcoming. "Salience and Taxation: Theory and Evidence.” American Economic Review.

Coats, Morris. 1995. “A Note on Estimating Cross-Border Effects of State Cigarette Taxes.” National Tax Journal, 48(4): 573-84.

Consumeraffairs.com. 2005. "Credit Card Companies Snuff Online Tobacco Sales,” March 17. http://www.consumeraffairs.com/news04/2005/tobacco_ags.html.

Evans, William, Jeanne Ringle and Diana Stech. 1999. "Tobacco Taxes and Public Policy to Discourage Smoking." In Tax Policy and the Economy, volume 13, ed. James Poterba, 135-154. Cambridge, MA: MIT Press.

Evans, William, Matthew C. Farrelly and Edward Montgomery. 2002. "Do Workplace Bans Reduce Smoking?" American Economic Review, 89(4): 728-747.

Farrelly, Matthew, Frank J. Chaloupka, and Terry Pehacek. 2001. "The Impact of Tobacco Control Program Expenditures on Aggregate Sales: 1981-1998." National Bureau of Economic Research Working Paper 8691.

General Accounting Office. 2002. "Internet Cigarette Sales: Giving ATF Investigative Authority May Improve Reporting and Enforcement.” GAO-02- 743, August 9. 
General Accounting Office. 2003. "Internet Cigarette Sales: Limited Compliance and Enforcement of the Jenkins Act Result in Loss of State Tax Revenue.” GAO03-714T, May 1.

Glasner, Judith. 2003. "U.S. Bill Targets Tobacco Sites," Wired News, June 6. http://www.wired.com/news/business/0,1367,59124,00.html.

Goolsbee, Austan and Jeffrey Brown. 2002. "Does the Internet Make Markets More Competitive? Evidence from the Life Insurance Industry." Journal of Political Economy, 110(3): 481-507.

Goolsbee, Austan. 2000. "In a World Without Borders: The Impact of Taxes on Internet Commerce.” Quarterly Journal of Economics, 115(2): 561-576.

Gruber, Jonathan and Bötond Koszegi. 2001. "Is Addiction Rational? Theory and Evidence." Quarterly Journal of Economics, 116(4): 1261-1305.

Gruber, Jonathan, Anindya Sen, and Mark Stabile. 2003. "Estimating Price Elasticities When There is Smuggling: The Sensitivity of Smoking to Price in Canada." Journal of Health Economics, 22(5): 821-842.

Keeler, Theodore E., The-wei Hu, Willard G. Manning and Hai-Yen Sung. 2001. "State Tobacco Taxation, Education, and Smoking: Controlling for Effects of Omitted Variables.” National Tax Journal, 54(1): 83-102.

Lewis, Truman. 2007. “Bill Targets Online Cigarette Sellers,” Consumeraffairs.com, July 11. http://www.consumeraffairs.com/news04/2007/07/cigarettes_online.html.

Lovenheim, Michael F. 2008. "How Far to the Border?: The Extent and Impact of CrossBorder Casual Cigarette Smuggling.” National Tax Journal, 61(1): 7-33.

Orzechowski and Walker, 2006. The Tax Burden on Tobacco: Historical Compilation, Volume 41. Arlington, VA: Orzechowski and Walker.

Ridgewood Economic Associates, Ltd. 2002. "New Cigarette Tax Revenue Sources for New York State.“ http://www.nyacs.org/Taxlossstudy2002.pdf.pdf.

Rubin, Robert. 2001. “Online Tobacco Sales Grow, States Lose.” Forrester Research, Incorporated, April 27.

http://www.forrester.com/ER/Research/Brief/Excerpt/0,1317,12253,00.html.

Slemrod, Joel and Wojciech Kopczuk. 2002. “The Optimal Elasticity of Taxable Income.” Journal of Public Economics, 84(1): 91-112. 
Stehr, Mark. 2005. “Cigarette Tax Avoidance and Evasion.” Journal of Health Economics, 24(2): 277-297.

Thursby, Jerry and Marie Thursby. 2000. "Interstate Cigarette Bootlegging: Extent, Revenue Losses, and Effects of Federal Intervention.” National Tax Journal, 53(1): 59-78.

Yonish, Steve, James L. Mcquivey, Gillian Demoulin, Jennifer Gordon, Resa Broadbent. 2001. "Why Technographics Works," Forrester Research, Incorporated, November. http://www.forrester.com/ER/Research/Report/Summary/0,1338,11797,00.html.

Yurekli, Ayda A. and Ping Zhang. 2000. "The Impact of Clean Indoor-Air Laws and Cigarette Smuggling on the Demand for Cigarettes: An Empirical Model." Health Economics, 9(2): 159-170. 
Table 1. Means of Selected Variables by Year

\begin{tabular}{|c|c|c|c|c|c|c|}
\hline \multicolumn{7}{|c|}{ Panel A: All States } \\
\hline \multirow{2}{*}{$\begin{array}{l}\text { Variable } \\
\text { Sales/canita (nacks) }\end{array}$} & \multicolumn{2}{|c|}{$\begin{array}{c}\text { Mean (S.D.) } \\
\text { FY } 1980\end{array}$} & \multicolumn{2}{|c|}{$\begin{array}{c}\text { Mean (S.D.) } \\
\text { FY } 1990\end{array}$} & \multicolumn{2}{|c|}{$\begin{array}{c}\text { Mean (S.D.) } \\
\text { FY 2000 }\end{array}$} \\
\hline & 129.00 & 18.63 & 100.84 & 19.72 & 76.26 & 24.81 \\
\hline $\ln$ (Sales/capita) & 4.85 & 0.13 & 4.60 & 0.19 & 4.28 & 0.33 \\
\hline Consumption/capita (packs) & n.a. & n.a. & 82.29 & 13.34 & 72.79 & 15.54 \\
\hline $\ln$ (consumption/capita) & n.a. & n.a. & 4.40 & 0.16 & 4.26 & 0.23 \\
\hline $\ln$ (consumption)-ln(sales) & n.a. & n.a. & -0.20 & 0.10 & -0.01 & 0.15 \\
\hline Real State Tax (2005 cents) & 38.21 & 11.38 & 48.76 & 18.04 & 73.36 & 36.43 \\
\hline ln(Real State Tax) (2005 cents) & 3.58 & 0.39 & 3.79 & 0.49 & 4.14 & 0.60 \\
\hline Real Wholesale Price (2005 cents) & 129.18 & 7.52 & 218.95 & 13.61 & 337.43 & 12.30 \\
\hline ln(income/capita) & 11.02 & 0.14 & 10.70 & 0.15 & 10.55 & 0.13 \\
\hline CPS Internet Penetration Rate & 0.00 & 0.00 & 0.05 & 0.02 & 0.40 & 0.05 \\
\hline Forrester Internet Penetration Rate & 0.00 & 0.00 & 0.00 & 0.00 & 0.49 & 0.04 \\
\hline Number of Excise Tax Changes & 69 & 1.08 & 71 & 1.19 & 52 & 0.72 \\
\hline Change in Log Real State Excise Tax & 0.11 & 0.25 & 0.28 & 0.32 & 0.46 & 0.41 \\
\hline Change in Internet Penetration & n.a. & n.a. & 0.30 & 0.05 & 0.23 & 0.03 \\
\hline \multicolumn{7}{|c|}{ Panel B: Top 10 Internet Growth States } \\
\hline Variable & \multicolumn{2}{|c|}{$\begin{array}{c}\text { Mean (S.D.) } \\
\text { FY 1980 }\end{array}$} & \multicolumn{2}{|c|}{$\begin{array}{c}\text { Mean (S.D.) } \\
\text { FY } 1990\end{array}$} & \multicolumn{2}{|c|}{$\begin{array}{c}\text { Mean (S.D.) } \\
\text { FY 2000 }\end{array}$} \\
\hline $\ln ($ Sales/capita) & 4.73 & 0.23 & 4.46 & 0.19 & 4.16 & 0.27 \\
\hline Real State Tax (2005 cents) & 42.44 & 13.74 & 56.19 & 21.54 & 76.80 & 32.64 \\
\hline Real Wholesale Price (2005 cents) & 130.02 & 9.29 & 220.60 & 9.94 & 345.76 & 11.77 \\
\hline ln(income/capita) & 11.04 & 0.11 & 10.71 & 0.16 & 10.58 & 0.16 \\
\hline CPS Internet Penetration Rate & 0.00 & 0.00 & 0.06 & 0.02 & 0.41 & 0.53 \\
\hline Number of Excise Tax Changes & 18 & 1.14 & 19 & 1.11 & 10 & 0.47 \\
\hline Change in Log Real State Excise Tax & 0.13 & 0.29 & 0.34 & 0.40 & 0.44 & 0.41 \\
\hline Change in Internet Penetration & n.a. & n.a. & 0.35 & 0.04 & 0.25 & 0.03 \\
\hline \multicolumn{7}{|c|}{ Panel B: Bottom 10 Internet Growth States } \\
\hline Variable & \multicolumn{2}{|c|}{$\begin{array}{c}\text { Mean (S.D.) } \\
\text { FY } 1980\end{array}$} & \multicolumn{2}{|c|}{$\begin{array}{c}\text { Mean (S.D.) } \\
\text { FY } 1990\end{array}$} & \multicolumn{2}{|c|}{$\begin{array}{c}\text { Mean (S.D.) } \\
\text { FY } 2000\end{array}$} \\
\hline $\ln ($ Sales/capita) & 4.86 & 0.15 & 4.61 & 0.21 & 4.32 & 0.32 \\
\hline Real State Tax (2005 cents) & 39.00 & 10.02 & 48.27 & 16.18 & 65.98 & 30.73 \\
\hline Real Wholesale Price (2005 cents) & 128.62 & 5.81 & 219.04 & 12.32 & 338.97 & 13.40 \\
\hline $\ln ($ income/capita) & 10.94 & 0.15 & 10.63 & 0.20 & 10.49 & 0.18 \\
\hline CPS Internet Penetration Rate & 0.00 & 0.00 & 0.04 & 0.01 & 0.35 & 0.03 \\
\hline Number of Excise Tax Changes & 11 & 0.99 & 8 & 1.03 & 10 & 0.82 \\
\hline Change in Log Real State Excise Tax & 0.04 & 0.11 & 0.15 & 0.16 & 0.35 & 0.36 \\
\hline Change in Internet Penetration & n.a. & n.a. & 0.25 & 0.04 & 0.21 & 0.03 \\
\hline
\end{tabular}

Notes: All means are at the state-level for the specified fiscal year and are weighted by state-by-year population.

"n.a." means data for the given fiscal year were not available. The change variables, which are the variables in the last 3 rows of each section, represent the change between 1980 and 1989 for FY 1980, the change between 1990 and 1999 for FY 1990, and the change between 2000 and 2005 for FY 2000. The average changes in the final 2 rows of each section represent the average change across states in each time period, not the change in the state averages across time periods. The top 10 Internet growth states are Utah, New Hampshire, Washington, Minnesota, Connecticut, Nebraska, Colorado, Wyoming, Arizona, and Idaho. The bottom 10 Internet growth states are Mississippi, West Virginia, Arkansas, Louisiana, New Mexico, Alabama, South Carolina, Texas, Kentucky, and New York. 
Table 2. IV Estimates of the Effect of Prices and Internet Penetration on Cigarette Sales, 1980-2005

\begin{tabular}{lcccccc}
\hline \hline & \multicolumn{7}{c}{ Dependent Variable: In(Sales/capita) } \\
\cline { 2 - 7 } & $\begin{array}{c}\text { Baseline } \\
\text { (i) }\end{array}$ & $\begin{array}{c}\text { CPS } \\
\text { (ii) }\end{array}$ & $\begin{array}{c}\text { CPS } \\
\text { (iii) }\end{array}$ & $\begin{array}{c}\text { Forrester } \\
\text { (iv) }\end{array}$ & $\begin{array}{c}\text { Years }>\text { 1989 } \\
\text { (v) }\end{array}$ & $\begin{array}{c}\text { CPS Years } \\
\text { Only } \\
\text { (vi) }\end{array}$ \\
\hline ln(t) & $-0.171^{* *}$ & $-0.112^{* *}$ & $-0.156^{* *}$ & $-0.159^{* *}$ & $-0.108^{* *}$ & $-0.134^{* *}$ \\
& $(0.018)$ & $(0.029)$ & $(0.021)$ & $(0.029)$ & $(0.036)$ & $(0.043)$ \\
$\ln (\mathrm{t}) *$ Internet & & $-0.192^{* *}$ & $-0.136^{* *}$ & $-0.125^{* *}$ & $-0.318^{* *}$ & $-0.286^{* *}$ \\
& & $(0.048)$ & $(0.041)$ & $(0.030)$ & $(0.077)$ & $(0.081)$ \\
$\ln (\mathrm{p})$ & 0.043 & -0.025 & 0.098 & 0.076 & 0.105 & 0.291 \\
& $(0.155)$ & $(0.090)$ & $(0.155)$ & $(0.066)$ & $(0.428)$ & $(0.412)$ \\
Internet & & $1.008^{* *}$ & $0.484^{* *}$ & $0.385^{*}$ & $2.063^{* *}$ & $1.938^{* *}$ \\
& & $(0.220)$ & $(0.177)$ & $(0.220)$ & $(0.596)$ & $(0.607)$ \\
Neighbors' ln(p+t) & -0.133 & -0.001 & -0.118 & -0.072 & -0.318 & -0.403 \\
& $(0.220)$ & $(0.181)$ & $(0.216)$ & $(0.117)$ & $(0.374)$ & $(0.396)$ \\
ln(income/capita) & $0.399^{* *}$ & $0.555^{* *}$ & $0.225^{* *}$ & $0.461^{* *}$ & 0.447 & 0.545 \\
& $(0.145)$ & $(0.115)$ & $(0.063)$ & $(0.112)$ & $(0.402)$ & $(0.463)$ \\
State-Specific Trends & & & & & & No \\
Year Fixed Effects & Yes & Yes & Yes & Yes & No & No \\
Observations & Yes & Yes & No & Yes & Yes & Yes \\
$\mathrm{R}^{2}$ & 1274 & 1274 & 1274 & 1078 & 784 & 343 \\
\hline \hline
\end{tabular}

Notes: Standard errors clustered at the state level are in parentheses: * indicates significance at the $10 \%$ level and ** indicates significance at the $5 \%$ level. All specifications include state fixed effects and are weighted by state-by-year populations. Neighbors' average border price $(\ln (\mathrm{p}+\mathrm{t}))$ is instrumented using neighbors' average border tax $(\ln (\mathrm{t}))$ in each specification. The variable $p$ refers to the state average wholesale price and t refers to the state average per-pack cigarette excise tax. The specification using the Forrester Internet penetration data includes years 1980-2001. CPS years refer to the fiscal years in which Internet penetration questions were asked in the survey: 1990, 1994, 1998, 1999, 2001, 2002, and 2004. 
Table 3. Average State Cigarette Excise Tax Rate Elasticities from Parameter Estimates in Table 2, FY 2000

\begin{tabular}{|c|c|c|c|c|c|c|}
\hline \multirow[b]{2}{*}{$\begin{array}{l}\text { Price Elasticity } \\
\text { Due to Tax Change }\end{array}$} & \multicolumn{6}{|c|}{ "Dependent Variable: In(Sales/capita) } \\
\hline & $\begin{array}{c}\text { No } \\
\text { Internet } \\
\text { (i) } \\
\end{array}$ & $\begin{array}{c}\text { CPS } \\
\text { (Year FE) } \\
\text { (ii) }\end{array}$ & $\begin{array}{c}\text { CPS } \\
\text { (No Year FE) } \\
\text { (iii) }\end{array}$ & $\begin{array}{l}\text { Forrester } \\
\text { (iv) }\end{array}$ & $\begin{array}{c}\text { Years }>1989 \\
(v)\end{array}$ & $\begin{array}{c}\text { CPS Years } \\
\text { Only } \\
\text { (vi) }\end{array}$ \\
\hline$\varepsilon^{t}$ - With Internet & & -0.189 & -0.210 & -0.221 & -0.236 & -0.267 \\
\hline$\varepsilon^{t}$ - No Internet & -0.171 & -0.112 & -0.156 & -0.159 & -0.108 & -0.134 \\
\hline Difference & & -0.077 & -0.054 & -0.062 & -0.128 & -0.133 \\
\hline P-Value of Difference & & 0.000 & 0.001 & 0.000 & 0.000 & 0.001 \\
\hline
\end{tabular}

Notes: This table shows the authors' calculations from equations (1) and (2) as described in the text. All averages are weighted by state-by-year populations. Neighbors' average border price $(\ln (\mathrm{p}+\mathrm{t}))$ is instrumented using neighbors' average border tax $(\ln (\mathrm{t}))$ in each specification. The specification using the Forrester Internet penetration data are for the years 1980-2001. CPS years refer to the fiscal years in which Internet penetration questions were asked in the survey: 1990, 1994, 1998, 1999, 2001, 2002, and 2004. The elasticities for the CPS years are for FY 2001. P-values of the difference between the two elasticities are from 10,000 bootstrap replications of the data (clustered at the state level). The P-value in each column represents the proportion of replications in which the elasticity with the Internet is smaller in absolute value than the elasticity without the internet. 
Table 4. IV Estimates of the Effect of Prices and Internet Penetration on Cigarette Smuggling Using the CPS Internet Penetration Measure, 1990-2000

\begin{tabular}{|c|c|c|c|c|c|c|}
\hline \multirow[b]{2}{*}{ Variable } & \multicolumn{3}{|c|}{$\begin{array}{l}\text { Dependent Variable: } \\
\ln (\text { consumption) }\end{array}$} & \multicolumn{3}{|c|}{$\begin{array}{c}\text { Dependent Variable: } \\
\ln \text { (consumption)-ln(sales) }\end{array}$} \\
\hline & (i) & (ii) & (iii) & (iv) & (v) & (iv) \\
\hline $\ln (\mathrm{t})$ & $\begin{array}{l}-0.024 \\
(0.035)\end{array}$ & & & $\begin{array}{l}0.185^{* *} \\
(0.041)\end{array}$ & & \\
\hline $\ln (\mathrm{t}) *$ Internet & $\begin{array}{l}-0.089 \\
(0.090)\end{array}$ & $\begin{array}{c}0.104 \\
(0.194)\end{array}$ & $\begin{array}{c}0.210 \\
(0.242)\end{array}$ & $\begin{array}{c}0.211^{*} \\
(0.123)\end{array}$ & $\begin{array}{l}0.798^{* *} \\
(0.347)\end{array}$ & $\begin{array}{c}0.308 \\
(0.357)\end{array}$ \\
\hline $\ln (\mathrm{p})$ & $\begin{array}{c}0.081 \\
(0.135)\end{array}$ & & & $\begin{array}{c}0.141 \\
(0.175)\end{array}$ & & \\
\hline Internet & $\begin{array}{c}0.245 \\
(0.451)\end{array}$ & $\begin{array}{l}-0.425 \\
(0.959)\end{array}$ & $\begin{array}{c}-0.833 \\
(1.165)\end{array}$ & $\begin{array}{l}-1.073^{* *} \\
(0.528)\end{array}$ & $\begin{array}{l}-3.378^{* *} \\
(1.487)\end{array}$ & $\begin{array}{l}-1.514 \\
(1.550)\end{array}$ \\
\hline Neighbors' $\ln (\mathrm{p}+\mathrm{t})$ & $\begin{array}{l}-0.275 \\
(0.191)\end{array}$ & $\begin{array}{l}-0.497 * * \\
(0.249)\end{array}$ & $\begin{array}{l}-0.475^{*} \\
(0.255)\end{array}$ & $\begin{array}{l}-0.161 \\
(0.309)\end{array}$ & $\begin{array}{l}-0.552 \\
(0.422)\end{array}$ & $\begin{array}{l}-0.625 \\
(0.400)\end{array}$ \\
\hline $\ln$ (income/capita) & $\begin{array}{c}0.006 \\
(0.393)\end{array}$ & $\begin{array}{l}-0.025 \\
(0.463)\end{array}$ & $\begin{array}{l}-0.091 \\
(0.441)\end{array}$ & $\begin{array}{l}-0.154 \\
(0.600)\end{array}$ & $\begin{array}{l}-0.802 \\
(0.619)\end{array}$ & $\begin{array}{l}-0.607 \\
(0.599)\end{array}$ \\
\hline $\ln (\mathrm{t})^{*}$ year & & & $\begin{array}{l}-0.003 \\
(0.007)\end{array}$ & & & $\begin{array}{c}0.015 \\
(0.011)\end{array}$ \\
\hline $\ln (\mathrm{p})^{*}$ year & & & $\begin{array}{l}-0.035 \\
(0.060)\end{array}$ & & & $\begin{array}{c}0.092 \\
(0.078)\end{array}$ \\
\hline State-specific Elasticities & No & Yes & Yes & No & Yes & Yes \\
\hline Observations & 526 & 526 & 526 & 526 & 526 & 526 \\
\hline $\mathrm{R}^{2}$ & 0.86 & 0.90 & 0.90 & 0.74 & 0.84 & 0.84 \\
\hline
\end{tabular}

Notes: Consumption data come from the BRFSS survey and are aggregated to the state level. The BRFSS data are only available from 1990-2000. All specifications include state and year fixed effects but not state-specific linear time trends. Neighbors' average border price $(\ln (\mathrm{p}+\mathrm{t}))$ is instrumented using neighbors' average border tax $(\ln (\mathrm{t}))$ in each specification. Standard errors are in parentheses clustered at the state level: * indicates significance at the $10 \%$ level and ** indicates significance at the 5\% level. State-specific elasticities refer to state fixed effects interacted with both $\ln (\mathrm{p})$ and $\ln (\mathrm{t})$. 
Table 5. Sensitivity Analysis of IV Estimates of the Effect of Prices and Internet Penetration on Cigarette Sales Using the CPS Internet Variable - Sample Splits

\begin{tabular}{lccccc}
\hline \hline & \multicolumn{5}{c}{ Dependent Variable: In(Sales/capita) } \\
\cline { 2 - 6 } & $\begin{array}{c}\text { No } \\
\text { Havens } \\
\text { Variable }\end{array}$ & $\begin{array}{c}\text { Less Than } \\
\text { (i) Casinos }\end{array}$ & $\begin{array}{c}\text { More than } \\
\text { 5 Casinos } \\
\text { (iii) }\end{array}$ & $\begin{array}{c}\text { High } \\
\text { Smuggling } \\
\text { (iv) }\end{array}$ & $\begin{array}{c}\text { Low } \\
\text { Smuggling } \\
\text { (v) }\end{array}$ \\
\hline $\ln (\mathrm{t})$ & $-0.121^{* *}$ & $-0.112^{* *}$ & $-0.144^{* *}$ & $-0.115^{* *}$ & $-0.124^{* *}$ \\
& $(0.031)$ & $(0.019)$ & $(0.042)$ & $(0.031)$ & $(0.036)$ \\
$\ln (\mathrm{t}) *$ Internet & $-0.171^{* *}$ & $-0.180^{* *}$ & $-0.269^{*}$ & $-0.184^{* *}$ & $-0.121^{*}$ \\
& $(0.057)$ & $(0.042)$ & $(0.121)$ & $(0.057)$ & $(0.063)$ \\
$\ln (\mathrm{p})$ & -0.023 & 0.035 & 0.027 & -0.099 & $0.133^{* *}$ \\
& $(0.098)$ & $(0.078)$ & $(0.122)$ & $(0.151)$ & $(0.076)$ \\
Internet & $0.965^{* *}$ & $0.813^{* *}$ & $1.361^{* *}$ & $0.921^{* *}$ & $0.700^{* *}$ \\
& $(0.265)$ & $(0.231)$ & $(0.528)$ & $(0.195)$ & $(0.278)$ \\
Neighbors' ln(p+t) & 0.023 & $0.385^{* *}$ & -0.289 & -0.203 & 0.137 \\
& $(0.178)$ & $(0.130)$ & $(0.213)$ & $(0.287)$ & $(0.113)$ \\
$\ln ($ income/capita) & $0.579^{* *}$ & $0.524^{* *}$ & $0.466^{* *}$ & $0.594^{* *}$ & $0.436^{* *}$ \\
& $(0.109)$ & $(0.098)$ & $(0.233)$ & $(0.226)$ & $(0.143)$ \\
Observations & & & & & \\
$\mathrm{R}^{2}$ & 1170 & 858 & 416 & 390 & 884 \\
\hline \hline
\end{tabular}

Notes: Standard errors are clustered at the state level in parentheses: * indicates significance at the $10 \%$ level and $* *$ indicates significance at the $5 \%$ level. All specifications include state and year fixed effects as well as state-specific linear time trends and are weighted by state-by-year populations. Neighbors' average border price $\left(\ln \left(\mathrm{p}^{+\mathrm{t})}\right)\right.$ is instrumented using neighbors' average border tax $(\ln (\mathrm{t}))$ in each specification. Pre-settlement refers to years prior to 1999. "Haven" states are Virginia, Kentucky, North Carolina, and South Carolina. Low and high smuggling states are taken from Table 8 in Lovenheim (2008). High smuggling states are states estimated to have more than $15 \%$ of smokers who purchase cigarettes in lower-price border states: Alabama, Arkansas, Washington, DC, Illinois, Indiana, Kansas, Massachusetts, Maine, Maryland, Nebraska, New Jersey, New York, Rhode Island, Washington, and West Virginia. Low smuggling states are all other states. 
Table 6. Sensitivity Analysis of IV Estimates of the Effect of Prices and Internet Penetration on Cigarette Sales Using the CPS Internet Variable - State and Year Specific Elasticities and Elasticity Trends, 1980-2005

\begin{tabular}{|c|c|c|c|c|c|}
\hline \multirow[b]{2}{*}{ Variable } & \multicolumn{5}{|c|}{ Dependent Variable: $\ln ($ Sales/capita) } \\
\hline & (i) & (ii) & (iii) & (iv) & (v) \\
\hline $\ln (\mathrm{t})$ & & $\begin{array}{l}-0.041^{*} \\
(0.021)\end{array}$ & & $\begin{array}{l}-0.138^{* *} \\
(0.034)\end{array}$ & \\
\hline $\ln (\mathrm{t}) *$ Internet & $\begin{array}{l}-0.225 * * \\
(0.059)\end{array}$ & $\begin{array}{l}-0.103 * * \\
(0.037)\end{array}$ & $\begin{array}{l}-0.147 * * \\
(0.038)\end{array}$ & $\begin{array}{l}-0.140 * * \\
(0.062)\end{array}$ & $\begin{array}{l}-0.105^{* *} \\
(0.041)\end{array}$ \\
\hline $\ln (\mathrm{p})$ & & $\begin{array}{l}0.255^{* *} \\
(0.104)\end{array}$ & & $\begin{array}{l}0.237 \\
(0.197)\end{array}$ & \\
\hline Internet & $\begin{array}{l}1.187 * * \\
(0.247)\end{array}$ & $\begin{array}{l}0.642^{* *} \\
(0.172)\end{array}$ & $\begin{array}{c}0.898 * * \\
(0.182)\end{array}$ & $\begin{array}{l}0.720^{* *} \\
(0.235)\end{array}$ & $\begin{array}{c}0.378 * \\
(0.208)\end{array}$ \\
\hline Neighbors' $\ln \left(\mathrm{p}^{+}+\mathrm{t}\right)$ & $\begin{array}{l}-0.063 \\
(0.202)\end{array}$ & $\begin{array}{c}0.019 \\
(0.076)\end{array}$ & $\begin{array}{l}-0.055 \\
(0.088)\end{array}$ & $\begin{array}{l}-0.078 \\
(0.178)\end{array}$ & $\begin{array}{c}0.099 \\
(0.071)\end{array}$ \\
\hline $\ln ($ income/capita) & $\begin{array}{l}0.538 * * \\
(0.116)\end{array}$ & $\begin{array}{l}0.523^{* *} \\
(0.072)\end{array}$ & $\begin{array}{l}0.537 * * \\
(0.079)\end{array}$ & $\begin{array}{l}0.285^{* *} \\
(0.069)\end{array}$ & $\begin{array}{c}0.432 * * \\
(0.072)\end{array}$ \\
\hline $\ln (\mathrm{t}) *$ year & & $\begin{array}{l}-0.005^{* *} \\
(0.002)\end{array}$ & $\begin{array}{l}-0.005^{* *} \\
(0.002)\end{array}$ & $\begin{array}{l}-0.000 \\
(0.003)\end{array}$ & $\begin{array}{l}-0.043^{* *} \\
(0.012)\end{array}$ \\
\hline $\ln (\mathrm{p})^{*}$ year & & $\begin{array}{l}-0.018 * * \\
(0.008)\end{array}$ & $\begin{array}{l}-0.008 \\
(0.007)\end{array}$ & $\begin{array}{l}-0.017^{* *} \\
(0.008)\end{array}$ & $\begin{array}{c}0.001 \\
(0.010)\end{array}$ \\
\hline U.S. Internet Penetration Rate & & & & $\begin{array}{c}0.174 \\
(0.230)\end{array}$ & \\
\hline Year & & & & $\begin{array}{c}0.077^{*} \\
(0.041)\end{array}$ & \\
\hline State-specific elasticities & Yes & No & Yes & No & Yes \\
\hline State-specific elasticity trends & No & No & No & No & Yes \\
\hline
\end{tabular}

Notes: Robust standard errors are in parentheses: * indicates significance at the $10 \%$ level and ** indicates significance at the $5 \%$ level. All specifications include state and year fixed effects as well as state-specific linear time trends, except for column (iii), which contains state fixed effects and state-specific linear time trends. All regressions are weighted by state-by-year populations. Neighbors' average border price $(\ln (\mathrm{p}+\mathrm{t}))$ is instrumented using neighbors' average border tax $(\ln (\mathrm{t}))$ in each specification. State-specific elasticities refer to state fixed effects interacted with both $\ln (\mathrm{p})$ and $\ln (\mathrm{t})$. 
Figure 1. State-Specific Tax Rate Elasticity Trends and FY 2005 Internet Penetration Rates

Panel A: 1980-1989

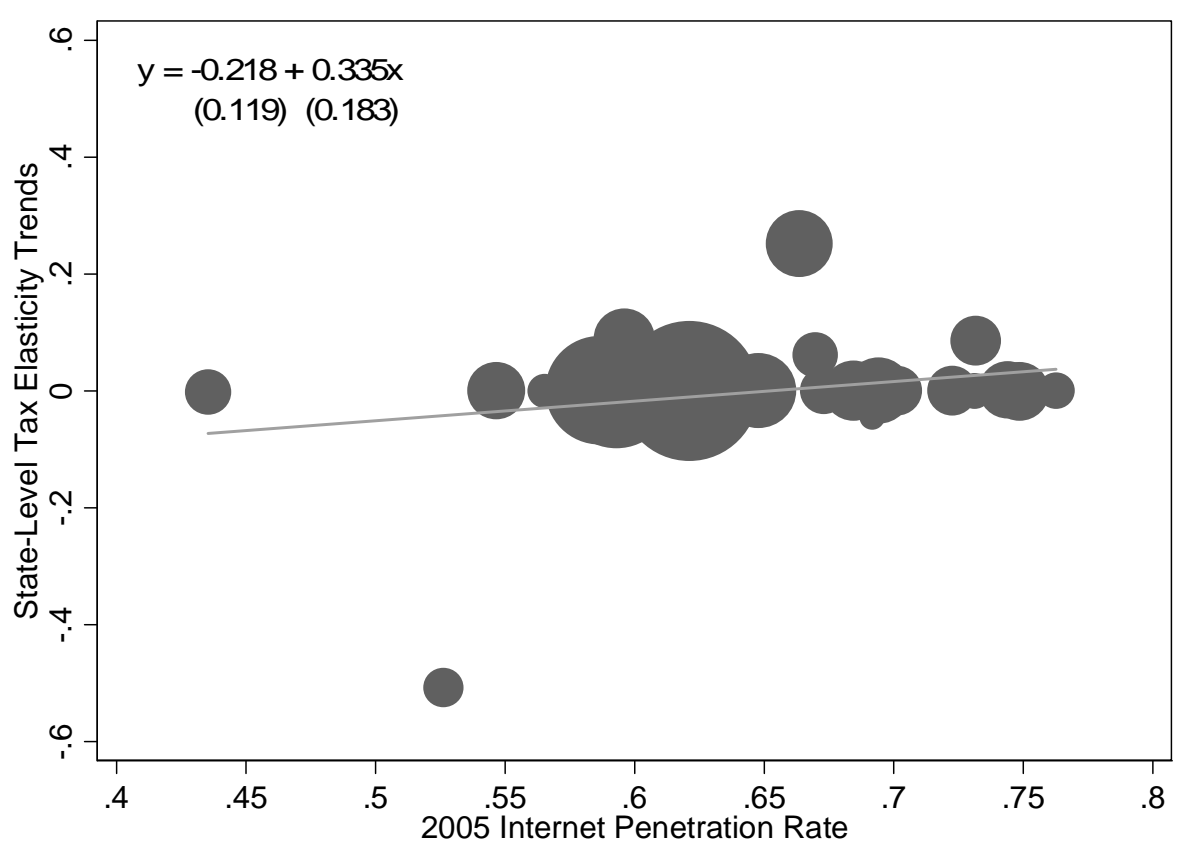

Panel B: 1990-2005

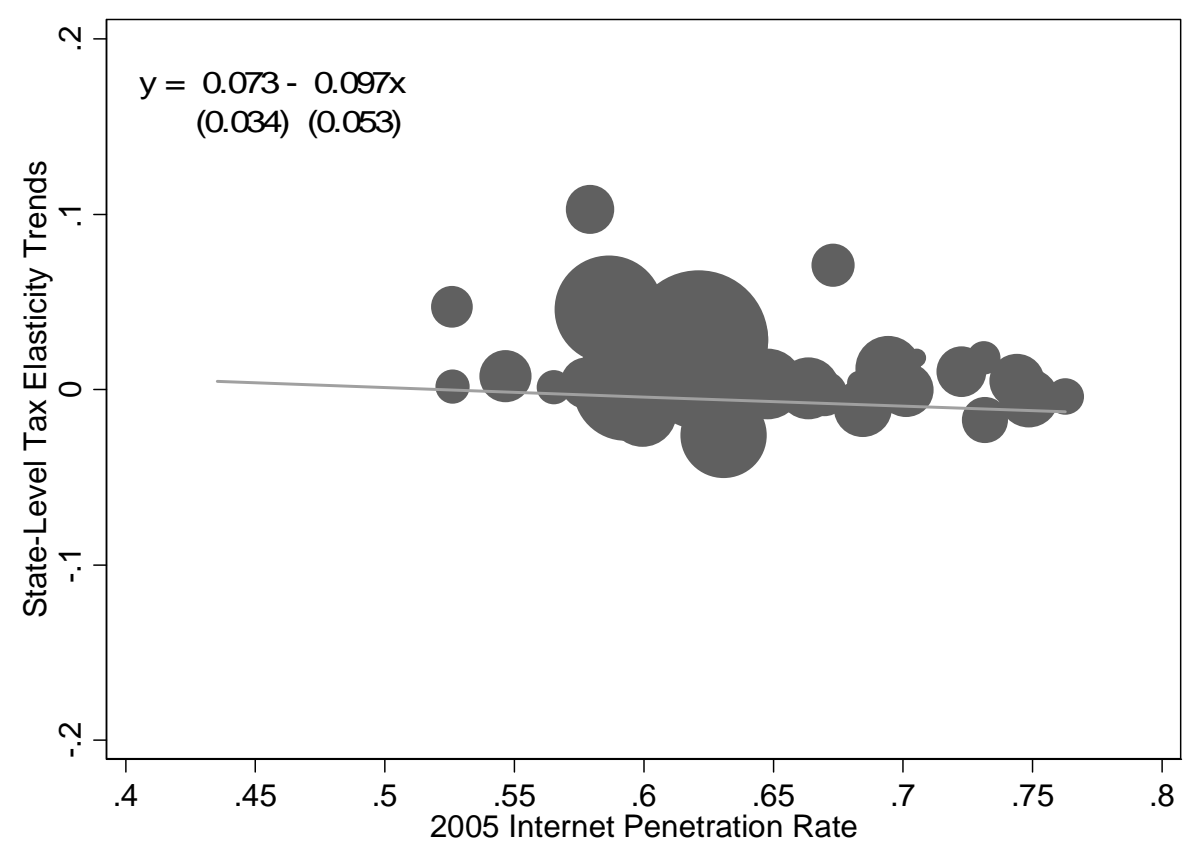

Notes: This figure shows estimated log real cigarette tax elasticity trends for each state plotted against each state's 2005 Internet penetration rate. The elasticity trends are estimated from a specification of equation (1) that excludes Internet terms and includes state-specific wholesale price and tax elasticities as well as state-specific wholesale price and tax linear elasticity trends. The regressions were estimated using state-by-year population totals as weights, and the size of each point reflects the average state population over the given sample period. Linear best-fit equations are shown in each panel with robust standard errors in parentheses. 
Figure 2. Year-Specific Tax Rate Elasticities and Internet Penetration Rates Over Time

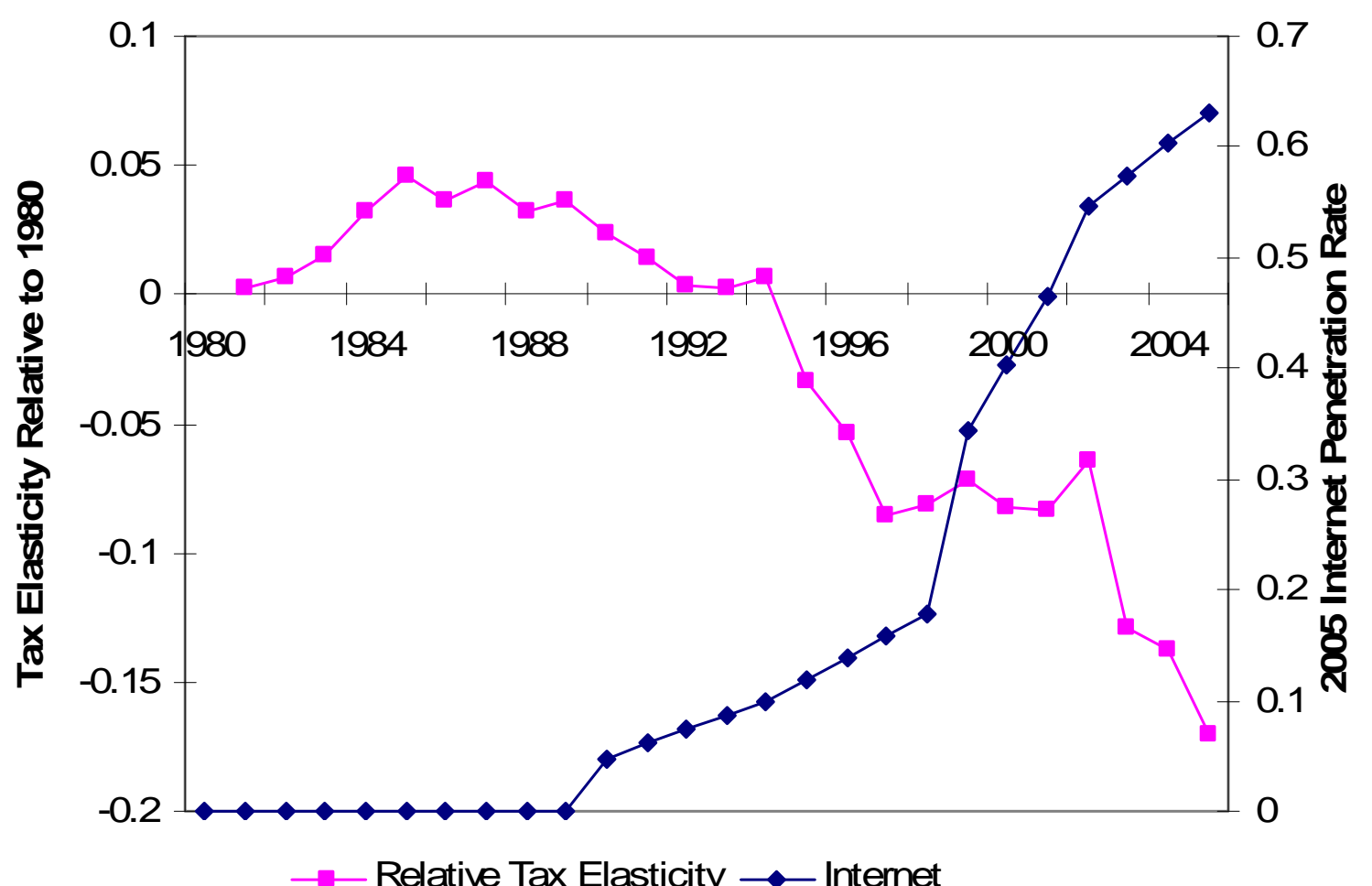

Notes: The figure shows yearly average Internet penetration rates as well as the coefficients from the interaction between year indicators and log real tax rates from a specification of equation (1) that excludes Internet terms and includes interactions between year and log real tax rates as described in the text. The regression was estimated using state-by-year population totals as weights and the Internet penetration means were calculated using these same weights. 